A careful examination of the conditions which gave rise to different types of the same diseases would repay the observer. Epidemics of scarlet fever and typhoid fever varied greatly in the intensity and characters of the predominant symptoms. Diphtheria, especially in relation to the paralysis which occurred afterwards, was also, in his opinion, a case in point. A study of the relationship of different forms of disease to each other and their influence on each other as rheumatic fever and scarlet fever, variola and typhoid, was a promising field of inquiry. Whether the liability to take small-pox again or after successful vaccination were due to want of care in the vaccination, or whether, as Sir James Paget suggested, a fresh modification of constitution might be brought about by some disease subsequent to vaccination, was also a fit subject for investigation. Mention was made by Paget of the occurrence of typhoid fever, in 1850 , in a town near Oxford; when small-pox broke out in 1865 it was shown by Mr. Daniel that out of 616 persons then revaccinated the result was unsuccessful in many, but by no means in all, and it also came out clearly that the successful revaccinations occurred chiefly or almost wholly among those who had had typhoid fever previously. Dr. Andrew was in clined to believe that a severe attack of typhoid fever did away with the protection afforded by vaccination. The development of inherited peculiarities, as well as the best mode of correcting hereditary diathesis, were also worthy subjects of observation. The best plan of erecting school buildings and dormitories, and the question of separate establishments for boys under and over twelve years, as was done at Christ's Hospital, with a view of diminishing the frequency and severity of epidemics in the London house, were also problems for consideration. Information, too, was wanted as to what were the best means to be adopted in case of an epidemic of scarlet fever and measles. In an instance in which the virus has been imported, perhaps complete isolation of the sufferers and possible carriers of infection would be effectual, and quarantine ought to extend as long as the maximum period of incubation of scarlet fever. In many instances there would be some difficulty, because no certain diagnosis would be possible. When the epidemic is raging, the question, Ought the school to be broken up? will arise. Dr. Andrew confessed that he permitted the parents to take away their boys if they chose. Another matter was the importance of careful disinfection of the clothes; in many schools adequate means for proper disinfection did not exist. -Dr. FuluER (St, Nicholas's College, Lancing) said that in many schools there were no proper means of isolation. The maximum limit of the period of incubation of scarlet fever, in nis experience, might safely be put at fourteen days, and he always enforced quarantine for that space of time. He had waited for thirteen days without having a fresh case, but even then had been disappointed.-Dr. INGLE (The Leys School, Cambridge), Surgeon - Major LEver (Military College, Oxford), Dr. AldDer Suith, and the President, also made some remarks.-Dr. FYFFE (Clifton College) spoke of the value of a good sanatorium attached to a school. He asked how the origin of a case of scarlet fever occurring on the nineteenth day after another case could be explained. Dr. Clement Dukes had said that after eight days there need be no fear of new cases arising.-Dr. EVATT said that in a recent epidemic of measles at Woolwich he turned all his boys out into tents and marquees with satisfactory results.-Dr. FYFFE said that at Clifton he had three sanatoria, one for non-infectious cases, another for contagious skin diseases, and a third for acute specifics; but even here difficulties were to be encountered when the nature of a case was doubtful, so that in addition an observation room is required.-Mr. HoLDERNESS (Eton) thought that certificates stating that boys had not been in contact with contagions affections for a week or ten days before their return to school ought to be given.-Dr. ALDER SMITH said that he wished to state most strongly that every public school ought to be under the control of an undivided medical responsibility, with full power to act immediately occasion required it. It was well known that some masters were not nearly so particular as others. Moreover, it was unfortunate that so many differences of opinion existed amongst medical officers themselves. This fact was strongly illustrated by a review of the fifty replies which had been received to a circular form of inquiry drawn up by Dr. Alder Smith. For instance, in answer to the question, What length of time (dating from the appearance of the rash) do you insist upon before the pupil is allowed to rejoin school? the time given varies for scarlet fever from one month to three months, and the same difference of opinion was found by going through the whole list of questions proposed in the circular form of inquiry.-Mr. Coombs (Bedford County School) was strongly of opinion that certificates from parents or guardians were not of the least value, for infectious disorders might be caught whilst the pupils were en route to the school.-Dr. DoraAN (Shibden Industrial Schools) said that quarantine for three weeks was an excellent regulation when any doubt existed as to whether the boys came from an infeeted district.-Dr. BRETT (London Orphan Asylum) did not think certificates were of much value.-Dr. JoNEs (Epsom College) considered thatcertificates were of some good, though not of much importance. He was sorry to have to say that the parents did not always write the truth.-Mr. STEDMAN (St. John's Foundation Schools) also joined in the discus. sion.-Dr. SHELLY (Haileybury) thought that every school should have some place of isolation for the detention of doubtful cases. With regard to the certificate from the parents, stating that the boy had not been in contact with infection for a certain period before returning to school, he said that personal experience made him absolutely sure that it was of no value. He also spoke on the question of disinfection of clothes, and said that he believed the disinfection of the clothes of a measles patient might be accomplished by exposure to sunlight and air. German measles was in his experience much more difficult of disinfection.

The following resolution was moved by $\mathrm{Dr}$, ALDER SMITH, seconded by Dr. EVATT, and unanimously carried :"That the Council be requested to bring forward at the next meeting a series of resolutions on the best methods for the prevention of epidemic diseases in schools, and that the business of the meeting be the discussion of the resolutions with a view to their adoption." A copy of this resolution will be sent to every member at least three weeks before the next meeting takes place.

Dr. Thursfield (Leamington College), Dr. Fletcher (Highgate Grammar School), Dr. Pike (Malvern College), Dr. Jones (Epsom Medical College), and Dr. Tomkins (Female Orphan Asylum) were elected members of the Society.

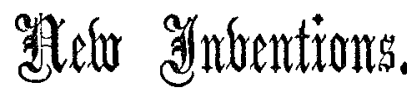

\section{THE COMPANION URINARY CASE.}

THE above-named case contains in very compact form all the appliances usually required in the examination of urine. It may be briefly described as follows :-An ordinary cylindrical two-ounce glass measure has closely fitted into it a test-tube, and into this again is placed a urinometer in case. At one end is a small spirit-lamp. Litmus and turmeric papers fill up a groove running lengthways. In the lid is a

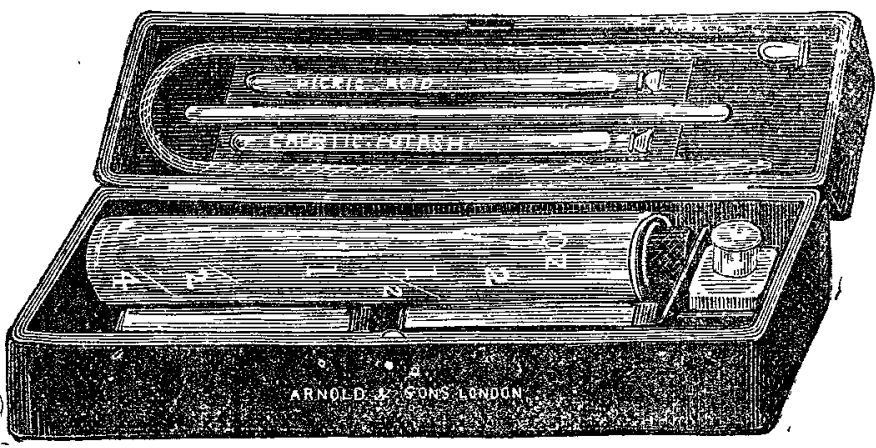

gum catheter, a glass stirring rod, and two delicate long glass-stoppered bottles for caustic potash and picric acid, With the contents of this case the urine can be drawn off, the amount measured, and the specific gravity and reactions to blue and red litmus paper taken. With the two chemicals, caustic potash and picric acid, and the aid of the spirit-lamp, pus, albumen, and sugar may be examined for. There is no strong acid to ooze out in carriage. The whole is contained in a case measuring seven inches long, one three-quarters deep, and the same in width. It has been made for me by Messts. Arnold and Sons of Smithfield.

T. Frederick Pearse, M.D. 